\title{
Oral immunotherapy with raw egg: immunological data at 6 and 18 months
}

\author{
PM Ojeda ${ }^{1}$, I Ojeda ${ }^{1 *}$, G Rubio $^{1}$, F Pineda $^{2}$ \\ From Food Allergy and Anaphylaxis Meeting (FAAM 2013) \\ Nice, France. 7-9 February 2013
}

\section{Background}

The efficacy, tolerability and immunological results of a SOTI regime with liquid pasteurized egg (SOTI-LPE) (both yolk and white) in 36 egg allergic children have already been published [1]. We present the immunological data at 6 (visit R1) and 18 months (visit R2) after completing SOTI.

\section{Methods}

By protocol skin prick testing (SPT) with egg white (EW), yolk (EY), ovoalbumin (OVA), and ovomucoid (OVM); specific IgE against white, yolk, OVA, and OVM, and specific IgG4 against OVA and OVM were performed at 6 and 18 months after completing the SOTI regime. The results were compared with those of the inclusion visit (B0).

\section{Results}

SPT showed a trend towards a decrease in the wheal surface area (mean in $\mathrm{mm}^{2} \mathrm{~B} 0$ vs mean R1, $\mathrm{p}$ value; vs mean R2, $p$ value): $E W$ 97.5 vs 38.0, $\mathrm{p}<0.0001$; vs $36.3, \mathrm{p}<0.001$; EY 33.5 vs $12.4 \mathrm{p}<0.0001$; vs $12.3, \mathrm{p}=0.003$; OVA 55.6 vs $19.1 \mathrm{p}<0.0001$; vs $17.3, \mathrm{p}<0.001$; OVM 109.6 vs 56.9 , $\mathrm{p}=0.005$; vs $44.8, \mathrm{p}=0.000$.

Mean sIgE values tended to increase at $\mathrm{R} 1$ and then decrease at $\mathrm{R} 2$ (IgE $\mathrm{kU} / \mathrm{L}$ B0 vs $\mathrm{R} 1, \mathrm{p}$ value; vs $\mathrm{R} 2, \mathrm{p}$ value): EW 12.2 vs $28.8, \mathrm{p}<0.0001$; vs $10.6, \mathrm{p}=0.322$; EY 9.4 vs $7.1, \mathrm{p}<0.0001$; vs $7.6, \mathrm{p}=0.069$; OVA 9,4 vs 11.6 , $\mathrm{p}=0.002$; vs $8.7, \mathrm{p}=0.95$; OVM 10.9 vs 24.2 , $\mathrm{p}<0.0001$; vs $8.9, \mathrm{p}=0.015$.

Mean sIgG4 values significantly increased (IgG4 mg/L B0 vs R1, p value; vs R2, p value): OVA 1.2 vs 16.9 , $\mathrm{p}<0.001$; vs $18.9, \mathrm{p}<0.001$; OVM 1.1 vs $5.0, \mathrm{p}<0.001$; vs 8.1, $\mathrm{p}<0.001$. IgG4 increases were also seen in patients not acquiring clinical tolerance to LPE.

${ }^{1}$ Allergy, Clínica de Asma y Alergia Dres. Ojeda, Madrid, Spain

Full list of author information is available at the end of the article

\section{Conclusion}

Global immunological results indicate significant changes suggesting the stimulation of immunological tolerance pathways in egg allergic children treated with SOTI-LPE: a decrease in skin reactivity and increase of sIgG4 antibodies. As a whole, IgE antibodies did not significantly change at 18 months as compared to baseline.

\section{Disclosure of interest}

None declared.

\section{Author details}

${ }^{1}$ Allergy, Clínica de Asma y Alergia Dres. Ojeda, Madrid, Spain. ${ }^{2}$ Research, Diater Laboratories, Madrid, Spain.

Published: 25 July 2013

Reference

1. Ojeda P, Ojeda I, Rubio G, Pineda F: Home-Based Oral Immunotherapy Protocol with Pasteurized Egg for Children Allergic to Hen's Egg. IMAJ 2012, 14:34-39.

doi:10.1186/2045-7022-3-S3-P18

Cite this article as: Ojeda et al:: Oral immunotherapy with raw egg: immunological data at 6 and 18 months. Clinical and Translational Allergy 2013 3(Suppl 3):P18.

Submit your next manuscript to BioMed Central and take full advantage of:

- Convenient online submission

- Thorough peer review

- No space constraints or color figure charges

- Immediate publication on acceptance

- Inclusion in PubMed, CAS, Scopus and Google Scholar

- Research which is freely available for redistribution 